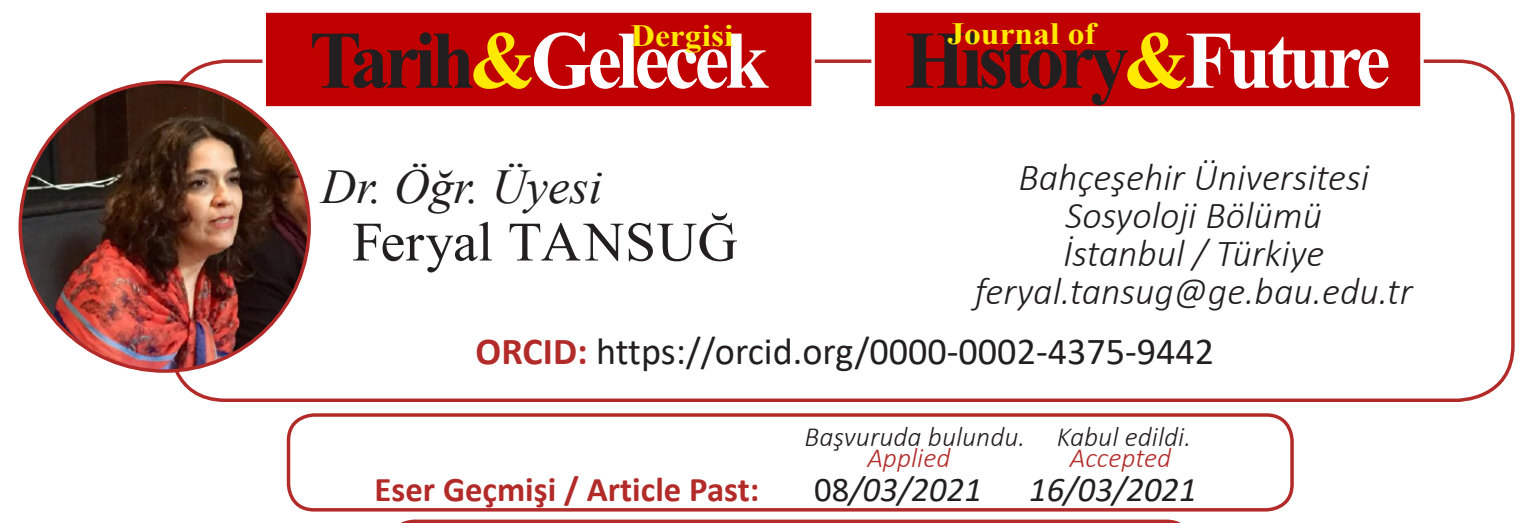

Araştırma Makalesi

DOI: http://dx.doi.org/10.21551/jhf.892864

Research Paper

Orjinal Makale / Orginal Paper

\title{
Tahayyül Edilen Bağımsızlık: Yunan İsyanı'nda Semadirek Adası
}

\author{
An Imagined Independence: The Island of Samothrace during the \\ Greek Revolt
}

\section{Öz}

On sekizinci yüzyılın sonlarında, on dokuzuncu yüzyılın başında, Aydınlanma Çağı'nın ve Fransız Devrimi'nin etkisiyle çok etnisiteli ve dinli imparatorluklarda çeşitli cemaatler, etnik, din ve dil birliği olan bağımsız devletlerini inşa etme arzusuna kapılmışlardı. Bu İmparatorluklardan birisi de Osmanlı İmparatorluğu idi. İmparatorluğun coğrafi konum olarak Avrupa'ya en yakın olan Balkan topraklarında bağımsızlık mücadelesi için Mora'daki Rumlar isyan başlatmıştı. İmparatorluk yönetiminde nüfusunun büyük bir çoğunluğu Rum Ortodoks Hıristiyan olan Ege Adaları'nın çoğu bu isyana katılarak Mora'daki bağımsızlık hareketi içinde yer almak istemişlerdi. Bu hareket içinde olmak kendilerine aynı dinden ve etnik gruptan oldukları aynı ve dili konuştukları millî siyasi birliğin parçası olmayı vadediyordu. $\mathrm{Bu}$ çağda zimmî olarak kendilerine ikincil statü atfeden Osmanlı idaresi tarafından yönetilmek istemediklerini isyana katılarak ifade etmişlerdi. 1821 Yunan İsyanına aktif olarak katılan Girit, Kıbrıs, Sisam ve Sakız adalarındaki olaylar araştırmalara konu olmuştur. Kuzey Ege'de küçük bir ada olan Semadirek'te bunlardan biriydi ve isyanın bastırılması sırasında ada neredeyse nüfusunun tamamını kaybetmişti. Ada'ya teknelerle gelen isyancıların örgütlemesiyle isyana katılan Semadirekli Rumlar, askerlerin kendilerine isyandan vaz geçmeleri ve Osmanlı'ya itaat etme telkinlerine 1srarla verdikleri kayıplara rağmen olumsuz yanıt vermişler. Bu makale, bilinmeyen Semadirek olayını ortaya çıkarırken Osmanlı otoritesi tarafından gördüğü sert muameleyi şiddet kavramı çerçevesinde incelemektedir.

Anahtar Kelimeler: Rum, Yunan, Osmanlı, Ege Adaları, şiddet, bağımsızlık, isyan, Semadirek 


\begin{abstract}
Multi religious and multi-ethnic empires' various populations had the aim of forming their independent states under the impact of the ideals of the Enlightenment and French Revolution at the end of the $18^{\text {th }}$ and beginning of the 19th centuries. Ottoman Empire was among these empires, too. The Serbs in the Balkans was the first group to revolt against the Ottoman rule in 1804. Greeks followed them in 1821 with an organized revolt which lasted until 1829 from which an Independent Greek Kingdom arose. The center of the revolt was the Balkan lands of the Empire, Morea Peninsula, which was the closest region to Europe. Therefore, it was not a coincidence that the rebellion broke in the region that first learned about political and intellectual developments in Europe. Production of printing press, newspapers and books, and the Greeks of the Empire who had western education in Europe played crucial role for the transmission of the Enlightenment ideals to the Greek community of the Empire. European travelers who began to travel in the Greek speaking lands of the Empire in the 1750s were interested in the architectural remnants of the ancient Greek civilization. For the Europe that admired ancient Greek Civilization's impressive architecture, philosophers' observation, and the political model "demos, the independence ideal of the Greeks in the Ottoman Empire was a striking event.

Hence, the Greek Revolt, which was called as the Greek Independence War by the Greeks, became a European ideal. The Ottoman imperial government's reaction to the revolt was very harsh since it saw it as a menace against the Ottoman reign and Sultan that protected the nonMuslims communities of the Empire through zimmî pact of Islamic Law for centuries. This pact guaranteed their lives, properties, and religion in return for payment of a specific tax (cizye) which was applied to only non-Muslims by the Islamic state in accordance with the Islamic law. Despite this regulation, the pact put the non-Muslims in a secondary position compared to the Muslims in the Empire. Sultan Mahmud II's reaction was very punitive since he could not understand the fact that rebellious Greeks were no longer wanted to be ruled by Muslim Ottoman dynasty as zimmîs with a secondary status. They wanted to have their independent states with their distinctive Greek identity. The Morea revolt in a short period of time spread to big and small Aegean islands through the activities of sea bandits with boats, Crete, Cyprus, Chios and Samos were among these islands. The severe punishment of the rebellious in Chios island, which was named as the Chios massacre in the literature shocked Europe. The bishop of the island, civil leaders of the Greeks (kocabaşıs), and representatives of Mastiha village were closed in the castle and assassinated by Ottoman soldiers. This event was followed by various mutual battles between the Greeks and soldiers in the island for seven years until 1828. There is another unknown shocking event in the island of Samothrace where almost half of its Greek inhabitants had been killed by the Ottoman soldiers, and women and children were enslaved to be sold in the slave markets with the order of the sultan. This article aims to reveal this unknown event by depending on the Ottoman archival documents and analyze the severe punishment of the Ottoman authority within the framework of violence.
\end{abstract}

Key Words: Rum, Greek, Ottoman, Aegean Islands, violence, independence, revolt, Samothraki 


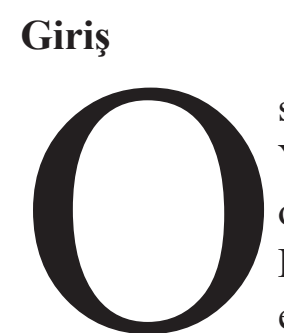

smanl1-Türk tarih yazıcıllğında Yunan İsyanı, Yunan tarih yazıcılığında Yunan Bağımsızlık Savaşı denildiği zaman hemen akla gelen iki çarpıcı olay dönemin Sultanı II. Mahmud'un (y. 1808-1939) talimatıyla Ortodoks Hıristiyan Patriği V. Gregorios'un (1746-1821) asılması ve Avrupa'da büyük etki yaratan Sakız Adası olayıdır. ${ }^{1}$ Yunan İsyanı Dönemi'nde ${ }^{2}$ olup bitenler, her iki tarih yazıcılığında akademik çalışmalara konu olmuştur. ${ }^{3} \mathrm{Bu}$ araştırmalara konu olmayan bir tanesi daha vardır ki bu da Semadirek Adası'ndaki olaydır. 1821 yılında yaklaşık 4.000-4.500 kişi olan ada nüfusunun yarısına yakını Osmanlı askerleri tarafından öldürülmüş, kadınlar ve çocuklar İstanbul ve İzmir'de esir pazarlarında satılmışlar, adada sadece 33 hane kalmıştır. Günümüzde bu olay, ölenleri simgeleyen bir terimle "Efkas" adıyla hâlâ 1 Eylül'de adanın merkez kasabası "tis Xoras" ta "Efkas" ismi verilen yerde anılmaktadır. "Efkas" kelimesi Yunanca "Yedi Yüz" anlamına gelen "Eftakosias" dan gelmektedir. Bu terim dağa çıkan ve orada öldürülen yedi yüz kişiyi sembolize ederken genel olarak ada halkının başına gelenleri tanımlamaktadır. Bu makale, olayın Osmanlı perspektifinden nasıl algılandığını Osmanlı arşiv belgelerine dayanarak ortaya çıkarırken Ege Denizi'nde kırsal hayat yaşayan küçük bir ada halkının 1821'de Mora'da çıkan Yunan İsyanı'na katıldığında Osmanlı otoritesi tarafından gördüğü sert muameleyi şiddet kavramı çerçevesinde incelemektedir.

\section{Aydınlanma Düşüncesi ve Osmanlı İmparatorluğu'nda Rumlar}

18. yüzyıl ve 19. yüzyılın başları, Avrupa aydınlanma düşüncesinin etkilerinin sürdüğü ve de Fransız Devrimi'nin yaşandığı bir dönemdi. Buna paralel olarak Avrupalı entelektüeller, ülkelerindeki siyasal rejimleri özgürlük ve demokrasi ideallerini temel alarak dönüştürme çabası içindeydiler. Bu çabanın amacı da romantik bir düşünce olarak etnik birlik, din ve dil birliği olan

1 Virginia H. Aksan, Ottoman Wars 1700-1870 [Osmanlı Savaşları] (Londra, New York: Pearson, 2007), 292. Sultan II. Mahmud tarafından Şeyhülislamlık'tan alınan fetvada adadaki asilerin katledilmesi, kadın ve çocukların esir alınması belirtilmişti. İsyanı bastırmaya giden Osmanlı askerleri kontrolden çıkıp isyan halinde bulunmayan Rum ahaliye saldırmışlardı. Mart sonunda kontrolden çıkan olaya bazı devlet adamları, din adamları, metropolitler müdahale ederek fesada karışmayanların affedilmesi için devreye girmeleriyle yeni bir irade yayınlanarak suçsuz olanların ayırt edilerek bağışlanması belirtildi. Zeki Arıkan, “Ayvalık İsyanı”, Belleten, C. 52, S. 203, (1993): 576.

2 Bu yazı Osmanlı arşiv belgelerine dayanılarak Osmanlı yönetimi perspektifini incelediğinden "Yunan İsyanı" terimi kullanılmaktadır.

3 Mübahat Kütükçüoğlu, "Yunan İsyanı Sırasında Anadolu ve Adalar Rumlarının Tutumları ve Sonuçları", Tarih Boyunca Türk-Yunan İlişkileri, Üçüncü Askeri Tarih Semineri Bildiriler, (Ankara: Genel Kurmay Basımevi, 1986), 133-157; Zeki Arıkan, “Ayvalık İsyanı,” Belleten 52:203 (1988): 571-600; Hakan Erdem, " "Do Not Think of the Greeks as Agricultural Labourers': Ottoman Responses to the Greek War of Independence" Citizenship and the Nation-State in Greece and Turkey, eds. Thalia G. Dragonas ve Faruk

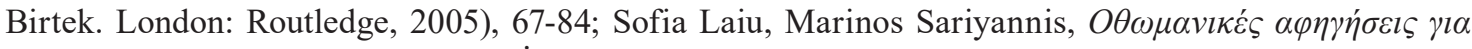

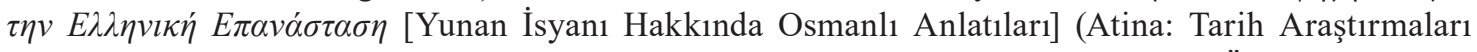

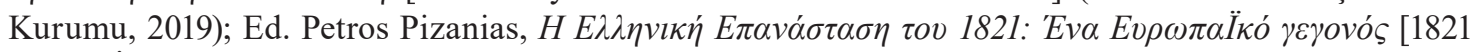

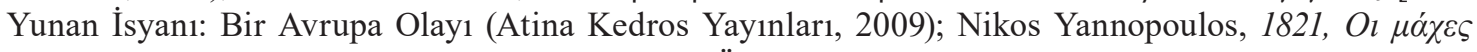
$\tau \omega v E \lambda \lambda \eta \dot{v} \omega \omega v \gamma l \alpha \tau \eta v \varepsilon \lambda \varepsilon v \theta \varepsilon \rho i ́ \alpha$ [1821, Yunanların Özgürlük Mücadelesi (Athens Historical Quest 2016);

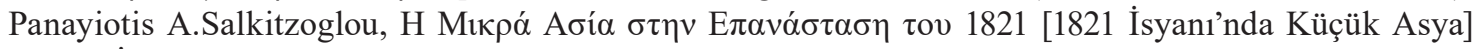
(Atina: İdrima Mizonos Ellinismou, 2010).

4 https://www.mixanitouxronou.gr/to-matomeno-kalokairi-tis-samothrakis-to-1821 Son ziyaret edilen tarih 6 Mart 2020. 
millî devletler inşa etmekti. Bu süreçte Avrupa, demokratik siyasi felsefesini dayandırdığ Yunan düşüncesine gıpta ediyor ve bu nedenle de 1821 yılında bağımsız bir Yunan halkı ve devletinin oluşumunu hedefleyen Mora'da çıkan isyanı sahipleniyordu. 1800'lü yılların başlarında Osmanlı İmparatorluğu'nun merkezî otoritesi zayıflamıştı; toprak ağalarının ya da ayanların ve de gayrimüslim cemaatlerin sivil liderlerinin diğer bir deyişle kocabaşıların köylü üzerinde güç kazandığı bir dönemdi. ${ }^{5} 18$. yüzyıl boyunca Rusya ile yapılan ekonomik ve politik olarak yıpratıcı savaşlar, 1804 Sırp isyanı ile başlayan ve Yunan isyanı (1821-1829) ile devam eden ve de bağımsız Yunan Krallığı'nın kurulmasıyla sonuçlanan Rumların bağımsızlık isyanları, Osmanlı yönetiminin meşruiyet sorunlarına işaret ediyordu.

Osmanlı İmparatorluğu'nda Rumlar arasında 17. yüzyılda başlayan ve 18. yüzyılda artan ekonomik gelişme, eğitim ve basın-yayın alanındaki faaliyetleri artırmıştı. 18. yüzyıla gelindiğinde ekonomik ve toplumsal gelişmeler üç yeni gruptan oluşan yeni bir toplumsal düzenin ortaya çıkmasına neden olmuştu: Birinci grupta hükümet görevlileri, Fenerli Rum Beyler (aristokrasi), dragomanlar -saray tercümanları- zengin tüccarlar, toprak sahipleri ve millet başları; ikinci grupta, tüccarlar, esnaflar ve imalatçılardan oluşan bir orta sınıf ve üçüncü grupta da köylüler vardı. En önemli gelişme tüccar sınıfının yükselişiydi. Bu sınıflar kazandıklarıyla oğullarını eğitim için Avrupa'ya yolluyor ve aynı zamanda İmparatorlukta okullar kuruyorlar, İmparatorluk içinde ve Avrupa kentlerinde de kitap basımını sağlıyorlard.$^{6}$ 18. yüzyılın son otuz yılında ve 19. yüzyılın ilk yirmi yılındaki entelektüel canlanmanın maddi temelini tüccarlar sağlamıştı ki bu da Ortodoks Hıristiyan kimliğinden daha ziyade millî Yunan (Helen) bilincinin gelişmesine neden olmuştu. ${ }^{7}$

Osmanlı Rum cemaatinin durumuna Osmanlı Devleti’nin gözünden değil Rumların gözünden baktığımızda İmparatorluğun Avrupa'ya en yakın bölgesi Balkanlarda dinî, etnik, dilsel, siyasi ve iktisadi temellerde ve toprak temelinde bütünleşme arzusu içinde oldukları görülür. Bu da Aydınlanma Çağı'nda ve Fransız Devrimi ile ortaya çıkan genel bir eğilimdi. Mora'daki ayaklanmayı örgütleyenlerin temel düşüncesi 19. yüzyılda artık adaletsiz olarak gördükleri Osmanlı İmparatorluğu'nun tebaası olmak değil, tahayyül ettikleri siyasi bütünleşmenin içinde özgürleşmiş bir halk olarak yer almaktı. ${ }^{8} \mathrm{Bu}$, hayal edilen siyasi birlik bütünleşmesinin temel iki özelliği sınırlarının belli ve bağımsız olması idi: Siyasi birlik ifadesi için öncelikle sınırları olmalıydı ve içinde bulundukları çağ gereği -Aydınlanma ve Fransız Devrimi- imparatorlukların var sayılan kutsal takdirle yönetimlerinin meşruluğunun sorgulandığı bir dönem de olduğu için bağımsız olmalıydı. ${ }^{9}$

5 Özcan Mert, “Tanzimat Dönemi’nde Çeşme Kocabaşıları (1839-1876)”, Ankara Universitesi Dil ve Tarih Coğrafya Fakültesi, Tarih Bölümü Tarih Araştırmaları Dergisi, C. 22, S. 35, (2004): 140; Veinstein, Gilles, "Le Patrimoine Foncier De Panayote Benakis, Kocabaşı de Kalamata," Journal of Turkish Studies, C. 11, (1987): 211-233; Feryal Tansuğ, "The Kocabaşıs as Intermediaries?: The Local and Central Administration in Imvros/İmroz and Lemnos in the Early 19th Century" [Aracı Kocabaş1lar: 19. Yüzyılın Başlarında İmroz ve Limni'de Yerel ve Merkezî Yönetim] Belleten, C. LXXVIII, S. 281, (Nisan, 2014): 223-244.

6 Gregory Jusdanis, Gecikmiş Modernlik ve Estetik ve Kültür, çev. Tuncay Birkan, (İstanbul: Metis Yayınlar1,1998), 43.

7 Richard Clogg, Concise History of Greece [Modern Yunanistan Tarihi] (Cambridge: Cambridge University Press, 1992), 27.

8 Jusdanis, Gecikmiş Modernlik ve Estetik ve Kültür, 48.

9 Benedict Anderson, The Imagined Communities, Reflections on the Origin and Spread of Nationalism [Hayali Cemaatler Milliyetçiliğin Kaynağı ve Yayılması Üzerine Düşünceler] (London, New York: 
Avrupa'da 16. yüzyılda şekillenmeye başlayan millî birlik fikri 18. ve 19. yüzyıllardaki ekonomik, siyasal ve sosyo-kültürel dönüşümün modernleşme olarak ifadelerinden birisiydi. Yunan seçkinlerinin ilk amaçladıkları modern özellik, millî siyasi birlikti. Batı Avrupa modernliğinden etkilenen Yunan entelektüellerinin ve tüccarlarının toplumlarının modernleşmesiyle kastettikleri Yunanca konuşan Ortodoksları milli bir cemaat olarak adlandırma, yaşadıkları toprakları Osmanlı yönetimi ve denetiminden kurtarma ve Yunanlıları Batılı olarak tanımlamaktı. Millî birliğe siyasal olarak ulaşmadan önce bu, söylem olarak millî kimlik fikri tartışılıyordu. ${ }^{10}$

Avrupalı gezginler Osmanlı İmparatorluğu'nun Yunanca konuşulan bölgelerine 1750'den sonra gelmeye başladıklarında modern Yunanlarla değil, antik Yunan eserleriyle ilgileniyorlardı. Bu gezginlerin Yunan (Helen) severliği Yunanistan'ın durumunu çarpıcı bir şekilde Avrupa'nın dikkatine sundu. Yunanistan'ın antik geçmişi ve Atina şehir devletinde doğmuş ve "halk için" anlamına gelen "demos" -ilk direkt katılımlı demokrasi yönetimi- düşüncesi, antik Yunan filozoflarının masalsı Yunan mitoloji tanrılarına ve anlatısına meydan okuyarak doğayı, insanları ve toplumu anlamak için aklî sorgulamayı ve şüpheci bir akıl ile anlamayı önermeleri Avrupa düşünce dünyasını ele geçirmişti. ${ }^{11}$ Mora'daki Rumların 1821'de başlattığı bağımsızlık savaşı mücadelesi yüzyılın en gözde uluslararası özgürlük hareketi olarak görülen ve bütün Avrupa'y1 etkileyen bir mesele olmuştu. Diğer gayrimüslim cemaatlere göre (Sırplar, Bulgarlar, ve Ermeniler gibi) Yunanlıların avantajı vardı: $\mathrm{Bu}$ da kendi millî tahayyüllerini Avrupa kimliğinin özüyle ilişkilendirmelerinden kaynaklanıyordu. Antik ve Modern Yunanistan arasındaki ideolojik bağlantı Yunan mücadelesini Avrupalı hale getirmişti. Adamantios Korais (1748-1833), İosipos Misiodaks (1730-1800), Daniil Filippidis (1775-1832), Grigorios Konstantas'1n (1758-1844) ve Velestinli Rigas (1757-1798) gibi Batılılaşma yanlısı Yunanlı entelektüeller, Osmanlı İmparatorluğu'nun Rum cemaatini, kendilerini aynı milletin ve Avrupa'nın mensupları olarak tahayyül etmeye teşvik etmek için Aydınlanma söylemini sahiplenmiş ve Avrupa'daki Helenseverlik (filhelen) ruhundan yararlanmışlard1. ${ }^{12}$ Etkili düşünür İosipos Misiodaks (1730-1800) Avrupa ile Yunanistan bağını açıklarken “Avrupa Yunanistan’ın yardımına koşarken aslında sadece başlangıçta ateşi Yunanlılardan almış olmanın borcunu ödüyordu." ${ }^{13}$ demişti. Bu düşünürler kurmayı hayal ettikleri bağımsız Yunanistan'ın hikâyesini Avrupa medeniyetinin tarihine entegre etmişlerdi. ${ }^{14}$

Osmanlı topraklarında Yunanların (Helenlerin) modernleşmesi ya da Avrupalılaşmaları, hukukun kodlanması sayesinde gerçekleşecekti ki bu da yeni bir siyasal örgütlenme, yani devlet gerektiriyordu. Yeni oluşan Yunan siyasi birliğine dâhil olmak isteyenler İmparatorluk yönetimine isyan etmekten çekinmemişlerdi. ${ }^{15} \mathrm{Bu}$ düşünceyle Mora'da isyanı hazırlayanlar, anakaranın iç taraflarında olmasa da nüfusun neredeyse tamamı Rum Ortodoks Hıristiyan olan Ege adalarında ve adalara yakın olan sahil kasabalarındaki Rumları etkileyerek isyana katılmalarını sağlamayı

Verso, 2006), 6-7.

10 Esra Özsüer, "19. Yüzyıl Avrupa Romantiklerinin 1821 Mora İsyanı Üzerindeki Siyasal ve Kültürel Etkileri”, Türkiyat Mecmuasl, C. 26, S. 2 (2016): 327.

11 Jusdanis, Gecikmiş Modernlik ve Estekik ve Kültür, 38.

12 Jusdanis, Gecikmiş Modernlik ve Estetik ve Kültür, 49-51; Özsüer, “19. Yüzyıl Avrupa Romantiklerinin 1821 Mora İsyanı Üzerindeki Siyasal ve Kültürel Etkileri”, 325-331; Herkül Milas, Geçmişten Bugüne Yunanlar (İstanbul: İletişim Yayınları, 2003), 173-175.

13 Jusdanis, Gecikmiş Modernlik ve Estetik ve Kültür, 49.

14 Jusdanis, Gecikmiş Modernlik ve Estekik ve Kültür, 39-40, 48-52.

15 Jusdanis, Gecikmiş Modernlik ve Estetik ve Kültür, 48-49. 
başarmışlardı: Girit, Sakız, Sisam, Semadirek, Kıbrıs, Kos ve Ayvalık gibi. ${ }^{16}$

Semadirek adası Rumları da bunlardan birisiydi. Büyük çoğunluğu Rum Ortodoks Hıristiyan olan Semadirek halkı, din, dil ve etnik kökenleriyle bağ kurdukları yeni oluşan Yunan millî kimliğinin ve siyasi birliğinin parçası olmak istediklerini aynı dinden ve etnik kökenden olmadıkları Osmanlı hanedanı tarafından yönetilmek istemediklerini hâlihazırda Mora'da çıkan isyana katılarak ifade etmekteydiler.

\section{Mora'da Rumların İsyanı}

19. yüzyıla kadar ne Rumlar ne diğer gayrimüslimler Osmanlılar tarafından yönetilme koşullarını sorgulamamışlardı. İslam hukukuna dayanan millet sisteminin ${ }^{17}$ gayrimüslimleri koyduğu zimmî statüsü, onlar için açıkça dile getirilen bir soruna veya toplumsal bir huzursuzluğa neden olmamıştı. 18. yüzyıl Aydınlanma Çağı düşüncesinin eşitlik ve özgürlük düşüncesinden etkilenen Balkan entelektüelleri, cemaatlerini de etkilemişlerdi.

Osmanlı İmparatorluğu, İslam hukukuna uygun olarak kitap dinlerini yani Hıristiyanlık ve Yahudiliği kutsal sayar ve tanırdı. Gayrimüslimlere dinî özerklik tanımasına rağmen, Müslüman olmayanlar hukuki olarak ikincil statüdeydi ve de bölgeden bölgeye değişmekle beraber belli ayrımcılıklara tâbi olabiliyorlardı: Gayrimüslim olmalarından kaynaklanan cizye vergisi vermek, bazı bölgelerde silah taşıyamamak, mahkemede Müslümanlara karşı şahitliklerinin kabul edilmemesi gibi. ${ }^{18}$ Bunlara ek olarak gayrimüslimler, fetihten önceki topraklarını kullanmaya devam edebilmeleri için haraç adiyla bir vergi verirlerdi. Bu vergi, toprak ve ürün üzerinden ayni olarak toplanırdı. Ayrıca, yetişkin ve sağlıklı erkeklerden cizye ya da baş vergisi denilen vergi, askerlik hizmetinden muaf tutulmaları karşılığında alınırdı. ${ }^{19}$ Tüm bu düzenlemeler İslam hukukunun zimmî anlaşmasına göre yapılırdı. Gayrimüslimler, İslam devletinin, kendilerini ve haklarını koruma güvencesi (zimmet) altında, bu koruma karşılığı cizye vergisi vererek o İslam ülkesinde yaşarlardı. ${ }^{20} 1821$ 'deki isyan Mora'daki Rumlar (zimmîler) tarafindan örgütlenerek başlamıştı. 1814 yılında Odesa'da kurulan Filiki Eteria Cemiyeti (Dostlar Derneği) bu hareketin temelini oluşturmuştu. 1814'te kurulduktan sonra ilk iki yıl 30 üyesi olan derneğin 1821 y1lına kadar 1000 üyesi olmuştu. Eflak Hospodarı Konstantin Ipsilantis'nin oğlu olan ve Rus ordusunda asker olan Aleksandr Ipsilantis, isyanın örgütlü bir şekilde başlamasına liderlik ederken Rus Çarı I. Aleksandr'dan destek sözü almıştı. ${ }^{21}$ Üyelerinden çoğu tüccar ve gemici olan dernekte din adamları/papazlar ve kleft denilen dağ eşkıyaları da vardı ki bu son grup örgütün silahlı mücadele kolunu oluşturmuştu. ${ }^{22}$ İpsilantis askerleriyle Boğdan'a geçip oradaki yönetimi ele geçirip (17

16 Kütükoğlu, "Yunan İsyanı Sırasında Anadolu ve Adalar Rumlarının Tutumları ve Sonuçlar1,” 137-140; Arıkan, "Ayvalık İsyanı", 571-601.

17 Halil İnalc1k, "The Status of the Greek Orthodox Patriarch under the Ottomans," Essays in Ottoman History ed. Halil İnalc1k (İstanbul: Eren Press, 1998), 196-199.

18 Gülnihal Bozkurt, Gayrimüslim Osmanlı Vatandaşların Hukukî Durumu (1839-1914) (Ankara: Türk Tarih Kurumu, 1989), 8-19; 40-59; Bilal Eryılmaz, Osmanlı Devleti’nde Gayrimüslim Tebaanın Yönetimi (İstanbul: Risale Yayınları, 1996). 17-18, 39-40.

19 Bozkurt, Gayrimüslim Osmanlı Vatandaşların Hukukî Durumu, 23, 26-27; Ery1lmaz, Osmanlı Devleti’nde Gayrimüslim Tebaanın Yönetimi, 17, 39.

20 Ahmet Yaman, "Zimmî”, DIA, C. 44, İstanbul (2017): 434.

21 Aksan, Ottoman Wars, 289.

22 Filiz Yaşar, Yunan Bağımsızlık Savaşı’nda Sakız Adası, (Ankara: Phoenix, 2006), 19. 
Mart 1821) Rus ordusunun geleceğini beklerken Bükreş’te Çar'ın sözünden vazgeçtiği ve İstanbul Ortodoks Rum Patriği'nden destek gelmeyeceği haberini aldı. ${ }^{23}$ Patrikhane'nin yanı sıra eğitimli, zengin Fenerli Rumların bir bölümü Yunan isyanına zemin hazırlayan aydınlanma düşüncesiyle yayılan bağımsızlık fikrine karşıydı. Patrik V. Gregorios, yazdığı risalelerle Avrupalı özgürlük fikrini savunanlara karşı çıktığını gösterdi ve de isyancıları aforoz etti. ${ }^{24}$ Cemaat başı Patriğin bu tutumu İmparatorluk'taki diğer din adamlarına ve genelde Rum cemaate ibret olarak asılmasına engel olamadı. Aynı tarihte Eflak'ta Sırp milislerinden Tudor Vladimirresku bir Romanya sosyal devrimi tasarlamıştı ve bunun için isyan düzenliyordu, amacı da Eflak ve Boğdan'ın İstanbullu Fenerli Beylerin idaresinden önceki durumuna getirilmesi idi. Bunu yaparken bölgedeki Rus toprak ağaları boyarların köylüleri sömürmeye dayalı sistemine karşı halkın desteğini almaya çalışıyordu. Vladimir 65.000 adamla Bükreş'e vardıktan kısa bir süre sonra İpsilantis de 5.000 başıbozukla varmıştı. Rus Çarı, İpsilantis'e destek vermediği gibi Osmanlıya değil Rus ayanları boyarlara karşı isyan başlatan Vladimir'den de desteğini çekmişti. Böylece Rus yardımı alamayan bu iki güç, zor durumda kalmıştı. Bu arada Boğdan'ın ele geçirildiği ilk günlerde Yaş (Jassy) ve Galati'de Müslümanlara yapılan eziyetler Osmanlı askerlerinin misillemesine neden olmuştu. Oluşan kaosta isyan 6 Nisan'da Mora'ya sıçramıştı. Bundan sonra sultan II. Mahmud Mora ve Eflak-Boğdan Beylikleri'ne asker göndermişti. ${ }^{25}$ Kleft liderler önderliğinde ayanlar ve zengin denizci patron tüccarların iş birliği ile organize edilen Mora İsyanı, Eflak ve Boğdan Beyliklerindekinden daha dayanıklı çıkmışı. 1821 yılının Mart ayı ortalarında dağınık, düzensiz bir direniş olarak başlayan hareket, Nisan'da örgütlü bir genel isyana dönüşmüştü. Bölgede bulunan Müslüman sakinler, isyanın getirdiği öfkenin hedefi oldu. Tahminen 40.000 Müslümanın bulunduğu Mora'da isyancılar tarafından yaklaşık 15.000 kişi öldürülmüş, bunu da Osmanlı askerlerinin Sakız Adası'nda ve bu yazıya konu olan Semadirek Adası'nda yaptıkları toplu öldürmeler izlemişti. Sakız'da metropolit, adanın kocabaşı1arı ve Mastika köyünün vekilleri 63 kişi kaleye kapatılarak irade-yi seniyyeye uygun olarak idam edilmişlerdi. İlerleyen günlerde de askerler Sakız Adası'nda öldürdükleri 500 kişinin kellerini İstanbul'a yollamışlardı. İsyan edenleri cezalandırmak ve korkutmak için alınan sert tedbirlerin başında ölüm cezası vardı. Bu, 26 Nisan 1821 tarihinde ilan edilen fetva ile İslam hukukuna uygun olarak meşrulaştırılmıştı. Münferit ve toplu halde yapılan isyanın cezası ölüm idi. ${ }^{26}$ Dönemin vezir-i azamı Salih Paşa Sakız Adası olayı ile ilgili yazdığı raporda askerlerin eylemlerini kontrol etmedeki zorluktan bahsetmişti. Yazısında asker denilenlerin isyan halinde olmayan köyleri yağmaladıklarını ve ahalisini köle olarak aldıklarını bildirmişti. Şeyhülislam bağışlanan Rum köylerindeki kadın-erkek ahalinin esir alınmasından yakınırken vezir-i azam Sakız Adası'ndaki birliklerin başındaki komutanı askerlerinin kanunsuz davranışları hakkında dikkatli olmasını tembihlediği yazısında büyük bir askerî disiplin problemine dikkat çekiyordu. ${ }^{27}$ Fizikî olarak Sakız'dan daha küçük olan Semadirek’te askerde böyle bir problem görülmemiş, aksine aşağıdaki bölümde görüleceği gibi, isyanı bastırmakla görevli Akdeniz Bahr-1 Sefid Muhafızı sultandan gelen ve gelecek emirlere tamamen itaat ettiğini ve edeceğini bildiriyordu.

23 Aksan, Ottoman Wars, 290

24 Milas, Geçmişten Bugüne Yunanlar, 212.

25 Aksan, Ottoman Wars, 290.

26 Kütükoğlu, "Yunan İsyanı Sırasında Anadolu ve Adalar Rumlarının Tutumları ve Sonuçları," 142-143.

27 Erdem, “'Do Not Think of the Greeks as Agricultural Labourers': Ottoman Responses to the Greek War of Independence", 67-84. 


\section{Osmanlı Askerlerinin İsyanı Bastırması}

Semadirek adasında -diğer kuzey Ege adaları ile beraber- 1479 yılında Osmanlı idaresi kesin olarak kurulmuştu. ${ }^{28}$ Diğer Ege adaları içinde en küçük olan Semadirek’te $\left(182 \mathrm{~km}^{2}\right)$ geniş sahiller vardı, ancak gemilerin barınmasına olanak verilen doğal limanlar yoktu. Adanın kuzeybatısında gemilerin demirlemesi için pek güvenli olmasa da Kamariotissa limanı vard $1 .{ }^{29}$ Mora' da başlayan Yunan İsyanı'na katıldığını ilan eden adalıların, bu fizikî özellik nedeniyle Ege Denizi'nde dolaşan isyancı teknelerden sürekli ve yeteri kadar destek alamadıkları düşünülebilir. Zira Osmanlı güçleri adadaki isyanı 1821 yılının Ekim ayı sonunda tamamen bastırabilmiş, nüfusunun çoğunu kaybeden adada bir daha isyana dair hareket olmamıştır.

Osmanlı yönetimi isyanları bastırmak için sadece fiziksel güç ve baskı kullanmamıştı. Sürgün, mülklerinin istimlak edilmesi ve hapsetme de Osmanlı yönetiminin isyanı bastırmak için kullandığ 1 yöntemler arasındaydı. ${ }^{30}$ Merkezî yönetimin amacı, sadece fiziksel şiddet ile isyanı bastırmak değildi, tüm bu yöntemlerle Rumlara İmparatorluk’taki ikincil zimmî statülerini hatırlatmak ve yeniden kabul ettirmekti. ${ }^{31}$

Akdeniz Boğazı Muhafızı Mehmed Paşa, 1821 yılının Ağustos ayı başında Ege’de gezen isyancı eşkıya tekneleri olduğunu, bunların adalara çıkıp Rum ahaliyi isyana teşvik etmeye çalışacağını bildirip Semadirek ve İmroz civarında eşkıya teknelerinin görüldüğünü ve adaları bunlardan korumak için yapılması gerekenler konusunda padişahtan izin istemiştir. ${ }^{32}$ Ancak Semadirek adasını korumak mümkün olmamış, on gün sonra, 14 Ağustos’ta, adaya “izbandut eşkıyaları" çıkıp adalıları silahlandırarak isyan ettiklerini duyurmuşlar. Kadı vekilini hapseden eşkıyaların toplam üç yüz kişi olduğu ${ }^{33}$ adanın kadısı üç gün sonra İstanbul'a bir not göndererek naibinin esir alındığını bildirilmiş. ${ }^{34}$ İlerleyen günlerde Semadirek ahalisi, adaya izbandut tekneleriyle gelenler tarafından örgütlenmesiyle isyana katıldığını duyurmuşlar. Bunu haber alan Sultan, Semadirek’te Osmanlı idaresine boyun eğmeyen zimmîlere karşı (Rumlara) cihat ilan edildiğini; adada bazı Müslümanların isyancılar tarafından öldürdüklerini bildiğini belirterek Muhafız Mehmed Paşa'nın ayaklanmayı bastırmaya gitmesi ve reayayı (Rum ahali) uyarması, karşı gelirler ise kimseyi kimseyi sağ bırakmadan (zi-ruh kalmayınca) öldürüp mallarının askerlere ganimet olarak verilmesi, kadın ve çocukların esir alınması hakkında 1821 yılının Ağustos ayının sonunda bir hüküm göndermişti. ${ }^{35}$ Bunun üzerine Boğaz Muhafizı Mehmed Paşa, icraatlarını merkezî yönetime yazdığı resmî yazılarla bildirmeye başlamıştır. İlerleyen günlerde, Semadirek adasında olan bitenler Muhafız ve adanın naibi tarafından yazılan yazılarda şöyle aktarılmıştı:

Cevdet Küçük, Ege Adalarının Egemenlik Devri Tarihçesi (Ankara: SAEMK, 2001), 4-5.

29 Christopher Wright, The Gattilusio Lordships and The Aegean World, 1355-1462 (Brill: Leiden, 2014), 19.

30 Kütükoğlu, "Yunan İsyanı Sırasında Anadolu ve Adalar Rumlarının Tutumları ve Sonuçları,” $143-146$.

31 Erdem, “'Do Not Think of the Greeks as Agricultural Labourers': Ottoman Responses to the Greek War of Independence", 70, 72-73

32 BOA (Devlet Arşivleri Başkanlığ 1 Osmanlı Arşivi), BOA, HAT 753/35559, 4 Ağustos 1821 (5 Zilkade 1236).

33 BOA, HAT 865/38552-C, 14 Ağustos 1821 (15 Zilkade 1236).

34 BOA, HAT, 865/38552-A, 17 Ağustos 1821 (18 Zilkade 1236).

35 BOA, C.DH Cevdet Dahiliye 141/7044, 28 Ağustos 1821 (29 Zilkade 1236) 
Boğaz Muhafızı Mehmed Paşa'nın Semadirek adasına 1000 kadar askerle 17 Eylül 1821'de vardığını, 19 Eylül 1821'de yazdığı resmî yazıdan (kaime) öğreniyoruz. Olayı savaş ve galibiyet (muhârebe ve galebe) terimiyle ifade ettiği yazısında; asilere itaat etmelerini önermiş ancak kabul etmediklerinden herkese örnek olacak şekilde cezalandırıldıklarını ve yirmi bir kesik başı İstanbul'a gönderdiğini, esirlerin de konuşturulmak üzere zapt olunan kendi kayıklarına bindirilerek yollanacağını bildirmiştir. Kötü huylu kâfirlerin hepsinin etkisiz hâle getirilmesi için uğraşılacağını da belirtmiştir. ${ }^{36}$ Boğaz Muhafızı, Semadirek'teki gayrimüslim halkın Arnavutlar ve izbanditleri (isyancıların Ege Denizi'nde dolaşan tekneleri) toplayarak azgınlık ve isyana cesaret ettiklerini bildirip adanın ele geçirilmesi ve kötü huylu kâfirlerin ortadan kaldırılmasını emreden fermanı aldığını ve tam olarak anladığını belirterek bin askerini yardımcısıyla adaya yolladığını yazmıştı. ${ }^{37}$ Mehmed Paşa yazısının devamında gerçekleştirdiği eylemleri -isyancıları ölümle cezalandırmayıaldığ 1 fermana itaat ederek gerçekleştirdiğini tekrarlayarak öne çıkarmıştır. Diğer bir deyişle Muhafız, verdikleri ölüm cezasının kaynağının bunları meşrulaştıran 26 Nisan 1821 tarihli fetva ${ }^{38}$ ve buna dayanan ferman olduğunun altını çizerek kendisin gelen emre tamamen itaat ettiğini belirterek yazısına şöyle devam etmiş̧tir: "Ele geçirilen bir korsan nefer sorgulandığında kötülük ve isyanlarını açıklamışlar ise de kendilerine devlete tâbi olmayı kabul ederek af dilemeleri ve savaştan vazgeçerek tövbe etmeleri defalarca teklif edilmiş ise de kabul etmemişlerdir. Bu nedenle kötülük, melanet ve galiz küfürleriyle savaşa girişip tüfek ile ateş açmaya cüret ettikleri için verilen fetva gereğince gelen fermanın maksadını yerine getirmek üzere Müslüman askerlerimiz Allah'ın birliğine dayanarak ve Peygamber Efendimizden yardım niyaz ederek hep birlikte hücum edip büyük bir savaş ve şiddetli çatışmalar olmuş, Allah'ın yardımı ve Hazret-i Peygamberin kerameti sonunda Müslüman gazilere zafer nasip olmuş; kötü huylu, melun, dinsiz kâfirler yenilgi ve perişanlığa uğrayıp her biri taşlık yerlere ve dağlara kaçmak isteseler de çok şükür ki bahse konu olan dinsizlerden dört kişisi canlı olarak yakalanmış, yirmi bir kişinin de uğursuz başları kesilmiş, kılıçtan geçirdikleri Müslümanlardan yalnız on kişi yaralanmış ve beş kişi de şehit olmuş. ${ }^{39}$ Muhafız, Semadirek'teki başarısını fetih olarak nitelendirip Sultan'ın kararının adaletine de gönderme yaparak yaptıkları eylemi meşrulaştırmıştır. Ardından isyancı gayrimüslimlerin (keferenin) tümüyle idamı için padişahtan haber bekledikleri ve gelene kadar esirleri şimdilik tutukladıklarını belirtikten sonra Muhafız'ın isyanı bastırmadaki başarısı için Sultan'dan taltif beklediği de okunmaktadır, zira satırlarının en başında adanın fiziksel yapısı nedeniyle az sayıda askerle bunu başarmanın mümkün olmadığını, ancak Allah'ın yardımı ve padişahın kerametiyle başardıklarını belirtmiş̧ir:

36 “...inhâ eylediği Semâdirek ceziresinde vuku bulan muhârebe ve galebe keyfiyetini mübeyyin müşârünileyhin evvelki gün (17 Eylül) vârid olup sürh işâretiyle takdim hâkipây-i hümâyûn-1 şâhâneleri kılınan kaimesi bâlâsına şeref-efzây-1 sudûr olan hatt-1 hümâyûn-1 şevket-makrûn-1 şehriyârîleri mucibince cezîre-i mezkûre usâtını hemen kırıp kahr u tenkil etmeye sa'y u ikdâm etmesini mübeyyin ... muharebe-i mezkûrede ahz olunan yirmi bir aded rüûs-1 maktûayı gönderdiğini ve alınan dilleri bundan böyle kendülerinin zabt olunan kayıklarına tahmilen irsâl edeceğini ..." Başbakanlık Osmanlı Arşivi (BOA) HAT 863/38478, 21 Zilhicce 1236 (19 Eylül 1821). Osmanlıca belgelerin yazar tarafından transkripsiyonu yapılırken Ferit Devellioğlu Sözlüğü’ndeki usul takip edilmiştir.

37 BOA, HAT 863/38478, 19 Eylül 1821 (21 Zilhicce 1236).

38 Dipnot 25.

39 BOA, HAT 863/38478, 19 Eylül 1821 (21 Zilhicce 1236). 
“...cezîre-i mezkûrenin zabt u teshîri ve kefere-i fecere-i mersûmûn külliyen idâm ve izâlesi cenâb-1 vâhibü'l-atâyâ hazretlerinden karîben memul ve müsted'â idüğü tebşir ve ifâdesinin sür'at-i vusulü mülâhazasıyla üserâ-yı mersûmun şimdilik tevkif ve kelle-i menhûseleri tesyîr kılınmış olup ... seyf-i düşmen-telef-i cihândârîlerin hemân hûn-1 a'dâ-yı dîn ü devletleriyle lem'a-rîz ü tâbdâr ve zill-i zalîl-i tâcidârîlerin kâffe-i bendegân-1 sadâkat-nişân ve cemî’ ehl-i îmân haklarında müstazıl ve sâyedâr eylemek da'vâtı vird-i zebân-1 çâkerânem olup işbu meserret-i azîme ve fütûhât-1 celîlenin tebşir ve işâası vesîle-i arz-1 kâlâ-y1 ubudiyetim olmuş olduğu bimennihi Teâlâ lede sa'di'lvusûl malum-1 devletleri buyuruldukda badezîn dahi hakk-1 âcizânemde mehâsin-i teveccühât-1 seniyyelerinin bîdirîğ ve şâyân buyurulmak bâbında ve her bir hâlde emr ü fermân hazreti men lehü'l-emrindir". ${ }^{40}$

İmparatorluk'ta toplu isyanlarda kesilen baş ve kulakların ibret için teşhir olunmak üzere İstanbul'a gönderildiği bilinmektedir. ${ }^{41}$ Semadirek'te de Sakız Adası'nda olduğu gibi aynı usul uygulanmıştır.

Max Weber, devleti belli bir toprak parçası üzerinde şiddeti kullanma tekelini meşru bir biçimde elinde bulunduran insan topluluğu olarak tanımlar. Burada belli bir toprak parçası, yani ülkenin alanı, tanımlayıcı özelliktir. ${ }^{42} \mathrm{Bu}$ tanımda dikkat edilmesi gereken husus, şiddeti kullanmanın meşru ve belli bir toprak parçası için olmasıdır. Devleti temsil eden Osmanlı Sultanı toprakları içinde yani hükmetme alanında bulunan Ege Adaları'ndaki isyan için şiddet uygulanmasına meşru olarak izin verebilecek tek siyasi otorite idi. Sultanın yöneticilerinden olan Muhafız Mehmed Paşa adada seri halde gerçekleştirdiği idamları Sultan'dan aldığı fermana dayandırarak ifade ederken yaptıklarını meşrulaştırmakta ve Sultan'ın temsilcisi olarak yapmaya devam etme arzusunda olduğunu belirtmektedir: Şöyle ki adalı isyancıları toptan öldürme emrinin kendisinden geleceğini umduğunu belirtip hatta Sultan'dan rica etmiştir: “...kefere-i fecere-i mersûmûn külliyen idâm ve izâlesi cenâb-1 vâhibü'l-atâyâ hazretlerinden karîben memul ve müsted'â idüğü ...". ${ }^{33}$ Bunun üzerine, Padişah, gelen yazıyı okuduğunu beyan ederek gelen havadisten duyduğu memnuniyeti şöyle dile getirmiştir: "Manzûrum olmuştur. Hak Teâlâ hazretlerinin lutf u ihsanına hamd ü senâ olsun. Vürûd eden rüûs-1 maktûa galtîde-i hâk-i ibret kılınıp müşârünileyhin tatarına hilat iksâ ve evvelki tahrirâtı müekkid ve tahsini hâvi cevâb tahrir oluna". ${ }^{44}$

Devletten başka (burada Sultan) diğer kişiler, fiziksel şiddet kullanma hakkını devlet (burada Sultan) izin verdiği ölçüde uygulayabilir. ${ }^{45}$ Şiddet kullanma kararı padişahın tekelinde olduğundan Muhafız ondan emir almadan isyancıları toptan öldürememektedir. Bu nedenle bahse konu olan esirlerin şimdilik tutuklandığını belirtir: “...üserâ-yı mersûmun şimdilik tevkif ve kelle-i

40 BOA, HAT 863/38478, 19 Eylül 1821 (21 Zilhicce 1236).

41 Kütükoğlu, Kütükoğlu, "Yunan İsyanı Sırasında Anadolu ve Adalar Rumlarının Tutumları ve Sonuçları”, 142.

42 Max Weber, The Vocation Lectures, "Science as a Vocation, "Politics as a Vocation" [Meslek Dersleri, "Meslek Olarak Bilim" "Meslek Olarak Politika] Çev: Rodney Livingstone (Indianapolis, Cambridge: Hackett Publishing Company, 2004), 33.

43 BOA, HAT 863/38478, 19 Eylül 1821 (21 Zilhicce 1236).

44 BOA, HAT 863/38478, 19 Eylül 1821 (21 Zilhicce 1236).

45 Weber, The Vocation Lectures, "Science as a Vocation, "Politics as a Vocation", 33. 
menhûseleri tesyîr kılınmış olup..." ${ }^{46}$ Semadirekli Rumların kendilerine itaat ve teslim olma teklif edilse de buna yanaşmamaları, sürekli öldürülmelerine rağmen kalanların yılmadan isyan eylemlerine devam etmeleri sadece Osmanlı sultanının yönetimini meşru olarak görmemelerinden kaynaklanmıyordu, aynı zamanda Yunan kimliği ile yapılan bağımsızlık hareketinden kopmak istemiyorlard1, bu nedenle isyandan vazgeçmeyerek şiddete de meydan okuyorlardı. Benzer şekilde Sisam ve Sakız adalarında da isyancıların Osmanlı askerleriyle çatışmayı, hatta savaşı göze almaları, Sakız'da isyancıların verdikleri tüm kayıplara rağmen isyana yedi yıl boyunca devam etmesi aşağıda bahsedilecek Max Weber'in tanımladığg meşru şiddete meydan okuduklarını gösteriyordu.

Semadirek adası Kadı Vekili Mehmet Aşir Efendi, 23 Eylül 1821'de ada ve Aleksandroupolis'e (Dedeağaç) bağlı Makri beldesi arasında isyancılarla ilgili gelişen olayları aktarmıştır. Bu belge, Semadirek'te kocabaşıların isyan etmeye direnmekte ve Osmanlı otoritesine meydan okumada son derece 1srarcı olduğuna örnektir:

Eylül ayının ortalarında Makri hâkimi efendiye dilekçe yollanarak Semadirek adasına kadı vekili yollanması istenmiştir. Söz konusu hâkim, kadı vekilini adaya göndermiş. Vekilin adaya gittiğinde silahların toplanmasını emretmiş olduğu duyulmuş. Adada silahları toplama işini yapacak altı Müslüman varmış, bunlardan dört kişisi evlat ve aileleriyle İnöz (Enez) tarafına gitmiş. Ramazan ayı başında Akdeniz muhafızı tarafından silahların toplanması için emir verilmiş ve mübaşir yollanmış. Mübaşir araştırıp bütün silahları toplayıp Ramazan ayının beşinci günü bir kayığa yükleyip muhafıza yollamış. Sonrasında geride kalan iki Müslüman, yanlarında iki de hizmetçileriyle Makri tarafına yola çıkmak üzereyken Ada sahiline Rum korsan birliği gelip karaya asker çıkarmış; kadı vekili ve Müslümanlar güçlükle yukarı çıkarak dağa kaçmışlar ve "korsan gâvurları" mahkemeyi basıp bazı yerleri kırıp dökmüşler. Kadı vekili ve dört Müslüman beraberce sahile inmişler, gayrimüslimlerden Makri’ye gitmek için bir kayık tedarik etmişler, yola çıkmak üzereyken Rum korsan teknesinin bıraktığı sandalda olan isyancılar (gâvurlar), bu kayığa da el koymuşlar ve kadı vekili ve yanındakileri öldürmek istemişler. Bu noktada belgede, yazıyı yazan kadı vekili Mehmed Aşir Efendi'nin onlara saldıran isyancılardan bahsederken "gâvur" terimi kullanırken, kendilerine Makri’ye gitmeleri için tekne veren Rumlara "gayrimüslim” terimi kullanması dikkat çekicidir. Vekilin, küçümseme içeren terimi isyancı Rumlar için kullanırken kendilerine tekne veren yerli Semadirekli Rumlar için tarafsız bir terim olan "gayrimüslim" i kullanması, iki grup Rum'1 ayırt ettiğine işaret etmektedir. Vekil ve beraberindekiler tekrar korsanlar tarafından saldırıya uğradıklarında yine dağa kaçmışlar ve yirmi iki gün kadar dağda saklandıktan sonra kocabaşılarına haber yollayıp kayık istemişler, "Gönderilmek olmaz, gelsinler otursunlar.” diye cevap almışlar. Kadı vekili mahkemeye geldiğinde kocabaşılar gelip onun silahlarını ve eşyalarını alıp başka yere nakledip hapsetmişler. Bu sırada başka bir adadan olup üç beş senedir Semadirek adasına yerleşen Agatengelos (Angelos) isimli keşişi kadı vekili makamına oturtarak alay etmişler. Bir türlü kurtarılamayan kadı vekili ve yanındakiler için Makri hâkimi bir kayık ve iki resmî yazı göndermiş. Adanın kocabaşıları yazıları alıp Rum korsanlara yollamışlar kayığı da kırmışlar. On gün sonra Makri'den tekrar bir kayık ve resmî yazı gelmiş, gene aynısını yapmışlar. Makri'ye gitmek için yapılan ricalar ve tartışmalar sonuçsuz kalmış. Hâl böyleyken, Bahr-1 Sefid (Akdeniz) Muhafızı Mehmet Paşa on altı kayık ve ile dört yüz civarında asker ile adaya gelmiş. Manol isimli bir çobanın yanına bir asker verilerek kocabaşılarına "Cizye evrakı 
vermeye geldik, başka işimiz ve size zarar ziyanımız yoktur.” diye haber yollamışlar. Aldıkları cevap Osmanlı otoritesine başkaldırıyı açıkça ifade etmektedir: Kocabaşılar "Bizler cizye evrakı bilmeyiz, gelmesinler, kendilerini öldürürüz." cevabını yollamışlar. Buna rağmen askerler hemen hücum etmeyip iki defa daha haber yollamışlar. Israr karşısında askerler hücum edip isyancıların bazılarını kılıçtan geçirmiş. Bazıları dağa kaçtıklarından askerler adayı zapt edip dağda olanları beşeronaridam etmeye başlamış. Nihayetinde kadı vekili ve yanındaki Müslümanlar kurtarılmışlar. ${ }^{47}$

Kadı vekilinin olayı aktardığı gün (23 Eylül 1821) on altı kayık 400 askerle adaya gelen Boğaz Muhafızı Mehmed Paşa da yazdığı resmî yazıda aynı gün olanları Sultan'a bildirmiştir. Yazısında Semadireklilerin isyanda gösterdikleri kararlı tutum, vazgeçmeleri için yapılan teklifi kesin bir dille reddetmeleri ve yukarıda kadı vekilinin bahsettiği Muhafız'ın dağa kaçanları orada idam etmesini, Muhafız Mehmed Paşa kendisi de bildirmektedir: "Muhafız memurluğunda bulunduğum Akdeniz Boğazı dışında bulunan Semadirek adası gâvurlarının ortaya çıkardığı isyan, asilik ve eşkıyalıklarından (isyân ve bagy ve şekavetlerine) dolayı bunların ezilmesi ve yok edilmesi (kahr u tedmirleri) hususuna padişah emri çıkarılıp çok şükür asker sevk ederek ve padişah hazretlerinin göstermiş olduğu yakınlığın uğuruyla ada zapt edilip kontrol altına alınmıştır. Bu ada çok sarp bir yer olduğu için gâvurlar dağlara kaçmışlarsa da adaletli olan padişahın himmetleri sayesinde dağlarda savaşılarak asiler yavaş yavaş yakalanarak kesik başları merhamet merkezi olan diyara (İstanbul) gönderilmekte olup; bu sefer cehennemlik kâfirlerden otuz dokuz adet kesik baş habercim tarafından size takdim edildi. Ayrıca konuşturulmak üzere üç adet esir alınmış ise de bunlar bekletilip bundan sonra ele geçirilecek esirler ile tarafinıza gönderilecek. Dağda bulunan gâvurlara, isyandan vazgeçme tercihini bildirsin diye firsat verilmiş ise de "Bizim askerimiz vardır, gelmeyiz, canlarımız dünya ve ahiret ateşine girene kadar uğraşırız." diye haber yolladılar. Bundan sonra düşmanlıklarını bildiğiniz kesik başların Allah'ın yardımıyla yavaş yavaş İstanbul'a yollanacağını arz ederek emirlerinizi beklerim. ${ }^{48}$

Mehmed Paşa, öldürme eylemlerini yaptığını yazıp padişahın emriyle ve yardımıyla başarılı olduğunu belirtirken Sultan'ın adaletine gönderme yaparak mutlak itaatini tekrar belirtmiştir. Adalı isyancıların, yapılan idamlardan, alınan esirlerden etkilenmeden eylemlerinden vazgeçmeyip direnmeyi tercih etmeleri küçük bir adadaki Rumlarının bağımsızlık hareketine bağlılıklarına ve Osmanlı idaresini kesin bir dille reddetmelerine işaret etmektedir. İsyanın tamamen bastırıldığı ve isyancıların hepsinin ortadan kaldırıldığını, "kötü niyetli kâfirlerden eser kalmadığını" Mehmed Paşa'nın ekim sonu yazdığı resmî yazıdan okuyoruz. Mehmed Paşa yazısında esirlerin elebaşlarının canlı olarak ele geçirildiğini, geri kalanının oldukları yerde idam edilip uğursuz başlarının İstanbul'a yollanması için Sultan'ın direktifini beklediğini de belirtmiştir. ${ }^{49}$ Kendisine gelen cevapta kötülüğün ve bozgunculuğun sebebi artık belli olduğundan Semadirek’te alınan esirlerin İstanbul'a getirip sorgudan geçirilmesine gerek olmadığı, Rumların gözünü korkutmak için isyancıların birkaç reisinin diri olarak gönderip geri kalanının adada idam ederek kesik başları yollamasını istenmiştir:

"Manzûrum olmuştur. İllahi'l-hamd Semadirek ceziresi külliyen feth ve teshîr olunup o gaile bertaraf olmuş madde-i fesâd ma'lûm oldu dillerin bu tarafa gelüp 
istintâk olunmaları beyhudedir bu tarafda siyâset olunup havane-i Rum'un gözlerini korkutmak için birkaç sergerdelerini hayyen irsâl edüp mâadâsını oltarafda idâm ile rüûs-1 maktûalarını göndersün." ${ }^{50}$

Dönemin sultanı II. Mahmud Osmanlı topraklarında siyasi denetimi tamamen eline almak için isyanı sert tedbirlerle cihat koşullarında, gayrimüslimlere savaş ilan ederek bastırmayı denemişti. 18. yüzyıldaki ademimerkeziyetçiliğe işaret eden gelişmelerden ${ }^{51}$ dolayı siyasi otoriteyi kendi denetimine almaya kalkışan -merkeziyetçiliği sağlayacak reformlara girişen- ${ }^{52}$ II. Mahmut için bu durum geleneksel Osmanlı siyasetinin bir parçasıydı. Şöyle ki Sultan, Şeyhülislam Yâsincizâde Abdülvehab Efendi'den sultana mutlak itaati telkin eden bir eser yazmasını istemişti. Şeyhülislam, Peygambere dayanarak hükümdara itaatin önemini anlatan Hülâsât el-Burhan fi İta'at el-Sultan isimli kitabı yazmıştı. ${ }^{53}$ Sultan için itaat koşulsuz şartsız İmparatorluk topraklarında yaşayan herkesten bekleniyordu. İsyan, Osmanlı sultanı için yüzyıllardır zimmet antlaşması çerçevesinde, atalarından beri Rumları himaye eden devlete ihanet etmek anlamına geliyordu. Rumlar için ise ilk bölümde açıklandığı üzere Avrupa'daki aydınlanma felsefisini temel alarak öne çıkarılan Yunan kimliği ile tasarlanan bağımsızlık hareketine dahil olmak ve din ve etnisite birliği içinde olmadıkları Müslüman bir hanedanlık olan Osmanlılar tarafindan ikincil statüde tebaa olarak yönetilmek istemediklerini ifade ediyordu. Semadirekliler, Yunan kimliği ortaya sürülerek başlatılan bağımsız siyasi birlik mücadelesine tâbi olmak için yaklaşık üç ay -Sakız ve Sisam adalarına göre çok kısa bir süre de olsa- elinden geldiği kadar direnmişti ta ki ada nüfusunun yaklaşık yarısı öldürülüp diğer yarısı esir edilip İstanbul ve İzmir esir pazarlarına gönderilene kadar. ${ }^{54}$

\section{Siyasi Güç ve Şiddet}

Hannah Arendt, siyaset bilimi teorisyenlerinin şiddetin, gücün aleni olarak tezahüründen başka bir şey olmadığına dair fikir birliği içinde olduklarını hatırlatır. Şiddet, isyancılara, yani çoğunluğun gücü tarafından yönetilmeyi kabul etmeyen fertlere karşı iktidar tarafindan kullanılan son çare olarak işlev görür. ${ }^{55}$ İncelenen belgelerin de gösterdiği gibi adada olan biten, meşruiyeti sorgulanan Osmanlı sultanının korkutmak yoluyla yaptı̆̆ı ve direnç gören bir güç gösterisiydi. Ancak şiddet yoluyla korkutma eylemi Sakız ve Sisam adalarında aynı sonucu vermemişti.

50 BOA, HAT 935/40464, 3 Safer 1237 (30 Ekim 1827).

51 Ariel Salzmann, "An Ancien Régime Revisited: Privatization and Political Economy in the Eighteenth Century Ottoman Empire" [Eski Rejimi Yeniden Düşünmek: 18. Yüzyıl Osmanlı İmparatorluğu'nda Özelleştirme ve Politik Ekonomi] Politics and Society, S. 21 (Aralık 1993): 393-423; Halil İnalcık, "Centralization and Decentralization" [Merkeziyetçilik ve Ademimerkeziyetçilik] Studies in Eighteenth Century Islamic History [18. Yüzyıl İslam Tarihinde Çalı̧̧malar] editörler T. Naff ve R. Owen (London, Amsterdam: Carbondale and Edwrdsville), 1977, 27, 41-43.

52 İlber Ortaylı, Tanzimat Devri'nde Osmanlı Mahalli İdareleri, 1840-1880 (Ankara: Türk Tarih Kurumu Yayınlar1: 2000), 54; Stanford J. Shaw ve Ezel Kural Shaw, History of the Ottoman Empire and Modern Turkey, 1808-1975 [Osmanlı İmparatorluğu'nun ve Modern Türkiye'nin Tarihi, 1808-1975] (Cambridge, New York: Cambridge University Press, 1977), 30-75.

53 Abdullah Taha İmamoğlu, Veli Karataş, "İrade-yi Seniyye-yi Hadislerle Desteklemek: II. Mahmud Dönemi Şeyhülislamlarından Yâsincizâde Abdülvehab Efendi ve Hulâsat el-Burhan fî̀ Ittiati's-Sultan Adlı Risalesi" Artuklu Akademi, C. 3, S. 1 (2016): 21-54.

54 Akademik olmayan bir kaynak görgü tanıklığına dayanarak Semadirek'te 25-30 aile kaldığını, onların da kötü şartlarda hayatlarına devam ettiklerini yazmıştır. https://www.mixanitouxronou.gr/tomatomeno-kalokairi-tis-samothrakis-to-1821/. Son ziyaret edilen tarih: 6 Mart 2020.

Hannah Arendt, On Violence [Şiddet Hakkında] (Orland, New York: A Harvest Book, 1970), 34, 51. 
Nüfusunun çoğunu kaybeden Semadirek'te Ekim sonunda isyan bitene kadar sessizlik hâkim olurken nüfusu daha kalabalık olan Sisam adasında isyan bastırılamamıştı. Sakız adasında ise durum daha farklıydı. Adaya gelen Sisamlılar, Sakızlıları ayaklanma için örgütlemişler, kaleye saldırılar düzenleyip defalarca kuşatmışlar (1821-1822, 1826-1828) ve kalabalık Sakız ahalisi Osmanlı askerlerine karşı koyan isyancılara katılmıştır. Sakızlılar -Sisamlıların desteği ile- Yunan Bağımsızlık Savaşı'nın bir parçası olmak istediklerini yedi yıl boyunca silahlı mücadeleye girişerek göstermişlerdi. İzmir ve Çeşme' den, farklı zamanlarda Sakız'a binlerce asker sevkiyatı yapılmasına ve büyük zayiat almalarına rağmen Sakızlılar yıllarca direnmişleri. Osmanlı güçlerinin adadaki isyanı bastırması 1828 yılını bulmuştu. ${ }^{56}$ Yıllarca direnmek Sisam ve Sakızlıları yıldırmamıştı, sultanın şiddet kullanarak yıldırma ve korkutma politikası işe yaramamıştı. II. Mahmud durumu yazdığı hatt-1 hümâyunda şöyle belirtmişti: "Bu Rum milletinin şu hareketleri akıl almaz bir şeydir. Bu kadar katlolundu bir taraftan da katlolunmakta iken asla bunlarda telaş ve tagayyür yoktur...".57

Machiavelli'nin yönetim sanatına dair bilinen eseri Prens'te belirttiği gibi hükümdar siyasi otoritesini ve meşruiyetini korumak için gücünü korkutmaktan almalıdır, ancak bunu yaparken kendisinden nefret ettirmemelidir. ${ }^{58}$ Her prens -yönetici- merhameti ile bilinmeyi ister, acımasızlığ 1 ile değil, ancak gene de merhamet niteliğinin kötüye kullanılmasına karşı tetikte olmalıdır. Zalim olmak bir prensin tebaasını bir arada ve itaatkâr tutmasına yarıyorsa prens zalimlik suçlamasını görmezden gelmelidir. ${ }^{59}$ II. Mahmud'un Yunan İsyanı sırasında Semadirek dâhil isyana katılan diğer adalarda güttüğü politika bu idi; önemli ve asıl olan tebaasının kendisine itaat etmesi idi, kendisinin nasıl bilindiği değil.

Osmanlı yönetimi açısından Cezair-i Bahr-ı Sefid muhafızı ve kadı vekilin isyancıların eylemleri için kullandıkları azgınlık (tuğyân), habislik (habâset) ve mel'anet (alçak) gibi terimlerin ifade ettiği gibi Rumlar haindi ve sultanın -ve atalarının- merhametini kötüye kullanmıştı. II. Mahmud, kendisine isyan edenleri bastırarak İmparatorluk genelinde Rum tebaayı sindirmek ve imparatorluğun birliğini sağlayıp kendi meşruiyetini sağlamlaştırmak için kendisinin zalim olarak anılmasına neden olacak şiddet hareketlerinde bulunmuştu. Semadirek ve Sakızadasında isyancıların direnişlerinin ilk aylarında toplu olarak öldürülmesi, çok sayıda kadın, çocuk ve ergen nüfusun esir edilip pazarlarda satılması, başkentte Patriği, bürokrasi ve diplomaside önemli pozisyonları olan Fenerli Rum ailelerin reislerini idam ettirmesi de diğer sindirme, korkutma eylemleri arasındadır. Çok dinli ve etnisiteli başkent İstanbul'da uygulanan şiddet, korkutma sınırlarında kalmıştı. Mora'daki isyan Bağımsız Yunan Devleti kurulmasıyla sonuçlanınca reisleri idam edilen Fenerli Rum ailelerin çocukları İstanbul'u, Osmanlı'yı terk etmemişler aksine 1830'dan sonra babalarını idam ettiren Sultan'ın, II. Mahmud'un, yakın hizmetinde tercüman, sultanın doktoru, şehzadelerin öğretmeni olarak ve II. Mahmud sonrasında isyan öncesi dönemde olduğu gibi bürokraside ve diplomaside önemli görevler üstlenmişlerdi. ${ }^{60}$ II. Mahmud, isyan eden adalarda -ve Ayvalık’ta-

56 Yaşar, Yunan Bă̆ımsızlık Savaşı’nda Sakız Adası, 52-53, 61-80.

57 Akataran Zeki Arıkan, "Yunan İsyanı'nın Başlangıcı,” Askerî Tarih Bülteni (Şubat 1987): 101.

58 Niccolo Machiavelli, The Prince [Prens] (New York: Dover Publications, 1992), 42-44.

59 Machiavelli, The Prince, 43.

60 Christine M. Philliou, "World, Old and New: Phanariot Networks and the Remaking of Ottoman Governance in the First Half of the Nineteenth Century" [Eski ve Yeni Dünya: Fenerli İletişim Ağları ve 19. Yüzyıl'ın Başında Osmanlı Yönetiminin Yeniden Yapılanması] (Doktora Tezi, Princeton Universitesi Tarih Bölümü, Princeton, 2004), 287-289, 309-314; Alexis Alexandris, The Greek Minority of Istanbul and Greek and Turkish Relations 1918-1974 [İstanbul'un Rum Azınlığı ve Yunan-Türk İlişkileri 1918- 
isyanın şiddet unsurlarıyla bastırılmasından sadece 10 y1l sonra, isyana aktif olarak katılan Sisam adasına yerli Rumlardan bir Sisam Beyi atayarak adada özerk yönetim kurulmasına razı olmuştur. ${ }^{61}$ $\mathrm{Bu}$, dönemin uluslararası olaylarının yarattığı politik zaruretten alınan bir karar da olsa II. Mahmud dönemi (y.1808-1839) sonrasında imparatorluk yönetiminin cemaatler arası problem yaşanan çok dinli ve etnisiteli bölgelere kendilerine mahsus nizamnamelerle yönetim izni verilmesine emsal teşkil etmiştir, 1845 'te Lübnan ve 1866 'da Girit adasına verilen nizamnameler gibi. ${ }^{62}$

\section{Sonuç}

Aydınlanma düşüncesinin özgürlük, eşitlik ve adalet fikirleri; Fransız Devrimi’nin entelektüel temelini oluştururken diğer Avrupa ülkelerinde de etkisini göstermişti. Mora'daki Yunan İsyanı'ndan (1821-1829) önce 1804'te İmparatorluğun Avrupa topraklarında Sırplar Osmanlı yönetimine karşı ayaklanmışlardı. Rum Ortodoks Hıristiyanların İmparatorluktaki kültürel ve dinî hâkimiyetine karşı -İstanbul Rum Ortodoks Kilisesi Patriğinin Rum olması ve Patrikhane'nin Ortodoks Hıristiyan olan diğer etnik grupların, Sırp, Bulgar gibi, dinî meselelerine karışması, ibadetin ve kutsal kitabın Yunanca okunmasında 1srar etmesi gibi- 18. yüzyılın sonlarında Romanya'da millî bir hareket başlamıştı. Bunlardan başka, Avrupa'da İspanya'da aynı ideallerle kralın mutlak monarşisine karşı anayasaya dayalı monarşi rejimi isteyen bir grup, isyan çıkarmıştı. Diğer bir deyişle Mora'daki isyan, çağa damgasını vuran Aydınlanma prensiplerinden ve devrime neden olduğu Fransa'dan etkilenerek organize olmuş isyanlardan birisiydi. Mora'daki Osmanlı Rum cemaatinin coğrafi konum olarak Avrupa'ya İmparatorluğun diğer bölgelerine göre daha yakın olduklarından çağın gelişmelerinden Avrupa'da neler olduğundan -basılan ve yayılan gazeteler, kitaplar ve Avrupa'da eğitim gören Rumlar sayesinde- haberdar olduklarından bu bağımsızlık idealinden etkilenmiş olmaları normaldi. İsyan, Mora'dan küçük büyük Ege adalarına denizde teknelerle gezen silahlı Rumlar tarafından yayılmıştı. Osmanlı Sultanı, yüzyıllardır İslam hükümdarı ve gayrimüslimler arasındaki zimmet güvencesi ile Osmanlı topraklarına yaşayan Rum cemaatin kendisine, devlete, neden isyan ettiğini anlayamamıştı. Osmanlı yönetimi tarafindan isyan, bir fesada, kötülüğe işaret ediyordu, isyancılar da asi ve eşkıya idi. Kuzey Ege'nin en küçük adası Semadirek'te Rum ahali isyana dışardan gelen teknelerin örgütlemesi ile katılmıştı. Akdeniz Boğazı Muhafızı Mehmed Paşa'nın isyancılar örgütlenmeden önce Ağustos ortalarında İstanbul'a ada civarında tehlike olduğu ve önlem alınması gerektiği konusunda yaptığı uyarı sonuçsuz kalmıştı. Dışarıdan gelen isyancı teknelerindekilerle örgütlenen Semadirek Rumları Osmanlı askerlerinin defalarca yaptıkları uyarılara rağmen isyandan vazgeçmemişler. Sultan'ın isyancıların cezasının idam olduğunu bildirmesi üzerine Muhafız Mehmed Paşa büyük bir itaat ile emre uyarak isyancı Rumları yakaladıkça idam etmiş, kadın ve çocuklar esir pazarlarına gönderilmişti. Neredeyse nüfusunun tamamını kaybeden adada bu olay hafizalarda yer etmiş "Efkas" adıyla anma günü olarak hatırlanmaktadır. Machiavelli, etkili bir yöneticinin nasıl olması gerektiğini tartıştığı ünlü

1974] (Athens: Centre for Asia Minor Studies, 1992), 28-30.

61 Mora'daki isyana denizde kolay hareket edebilen silahlı teknelerle güçlü destek vererek aktif olarak katılan Sisam Adası'ndaki isyanı denizde kolay hareket edemeyen ağır gemileriyle birçok defa denemesine rağmen başaramamıştır. Rusya yenilgisinden sonra 1829'de Edirne Antlaşması'nı imzalayarak Bağımsız Yunan Krallığı kurulmasına razı olan Osmanlı Devleti, Sisam Adası'nın durumuyla ilgili olarak Fransa, Rusya ve İngiltere'nin devreye girmesiyle, özellikle İngiliz elçisi Canning'in önerisi ve ssrarıly adada İmaparatorluk altında özerklik verilmesini kabul etmiştir. Ali Örenç, Tarih Dergisi, S. 36 (2000): 338341.

Ortayl1, Tanzimat Devri'nde, 51-53, 66-67. 
eseri Prens'te yöneticinin (Prens'in) amacının tebaasını parçalanmadan bir bütün olarak itaatkâr bir şekilde tutmasının önemini vurgular. Bunu yaparken de savaşması gerekiyorsa savaşmalıdır, çünkü siyasi idareyi elde tutmak için gerekli bir eylemdir, savaşsız hiçbir oluşum düşünülemez. Eseri boyunca Prens'in savaşı düzgün bir şekilde nasıl sürdürebileceğini anlatır. Prens siyasi birliğini ve otoritesini elinde tutmak için zor kullanabilir, devleti korumak için kendisinden korkulmasını tercih etmelidir, sevilmesini değil. ${ }^{33}$ II. Mahmud, isyan sırasında verdiği Semadirek'te -ve isyan eden her bölgede- isyancıların toptan öldürülmesi, kadın ve çocukların esir edilmesi emirleri ile kendisinden korkulmasını tercih etmiş̧ir. Machiavelli'ye göre kendisinden korkulmasının bir sınırı olmalıdır, Prens bunun seviyesini ayarlamada usta davranmalıdır, bu korku, nefrete ulaşmamalıdır ki yönetiminin meşruiyeti daimî olsun. 1821 yılının Ekim ayında bastırılan isyandan sonra ada, 1912 yılında Balkan Savaşları sırasında Bağımsız Yunan Krallı̆̆ı'nın (1821-1829 Mora İsyanı sonunda kurulan) yönetimine geçene kadar Osmanlı yönetiminde kalmıştır. Semadirek'teki Osmanlı geçmişinin mirası "Efkas” Meydanı ve 1 Eylül Anma Töreni iken, Sakız adasındaki mirası Nea Moni Manastırı'nda topluca öldürülenlerin kafataslarının ve kemiklerinin sergilenmesidir. Semadireklilerin yaşadıkları bu talihsizlik, yaklaşık doksan yıl sonra (1912) Bağımsız Yunan Krallı̆̆ı'nın temsil ettiği kültürel ve siyasi birliğe katılırken kendileri için kolektif bir anlatı vazifesi görmüştür.

\section{Kaynakça}

\section{Başbakanlık Osmanlı Arşivi}

C.DH, 141/7044, 28 Ağustos 1821 (29 Zilkade 1236)

HAT 753/35559, 4 Ağustos 1821 (5 Zilkade 1236).

HAT 865/38552-C, 14 Ağustos 1821 (15 Zilkade 1236).

HAT, 865/38552-A, 17 Ağustos 1821 (18 Zilkade 1236).

HAT 863/38478, 19 Eylül 1821 (21 Zilhicce 1236).

HAT 00869/38657- A, 23 Eylül 1821 (22 Zilkade 1236).

HAT 00863/38502, 23 Eylül 1821 (25 Zilhicce 1236).

HAT 935/40464, 30 Ekim 1827 (3 Safer 1237).

\section{Araştırma ve İncelemeler}

Alexandris, Alexis. The Greek Minority of Istanbul and Greek and Turkish Relations 1918-1974 [İstanbul'un Rum Azınlığı ve Yunan-Türk İlişkileri 1918-1974] Atina: Küçük Asya Araştırmaları Merkezi, 1992.

Arendt, Hannah. On Violence [Şiddet Hakkında]. A Harvest Book: Orland, New York, 1970.

Arıkan, Zeki. "Ayvalık İsyanı.” Belleten, C. 52, S. 203, (1993): 571-601.

Arıkan, Zeki. "Yunan İsyanı’nın Başlangıcı.” Askerî Tarih Bülteni (Şubat 1987): 97-132.

Eryılmaz, Bilal. Osmanlı Devleti'nde Gayrimüslim Tebaanın Yönetimi. İstanbul: Risale 
Yayınları, 1996.

Kütükoğlu, Mübahat. "Yunan İsyanı Sırasında Anadolu ve Adalar Rumlarının Tutumları ve Sonuçları.” Tarih Boyunca Türk-Yunan İlişkileri, Ü̧̧üncü Askeri Tarih Bildiriler, Ankara: Genel Kurmay Basımevi, 1986, 133-161.

Bozkurt, Gülnihal. Gayrimüslim Osmanlı Vatandaşların Hukukî Durumu (1839-1914). Ankara: Türk Tarih Kurumu, 1989.

İnalcık,Halil. “CentralizationandDecentralization”[MerkeziyetçilikveAdemimerkeziyetçilik] Studies in Eighteenth Century Islamic History [18. Yüzyıl İslam Tarihinde Çalışmalar] editörler Thomas Naff ve Roger Owen, 27-52. Carbondale ve Edwardsville: Southern Illionis University Press, 1977 ve London ve Amsterdam: Feffer and Simons, Inc, 1977.

Niccolo Michavelli, The Prince [Prens] Dover Publications, New York, 1992.

İnalcık, Halil. "The Status of the Greek Orthodox Patriarch under the Ottomans." Essays in Ottoman History ed. Halil İnalcık (İstanbul: Eren Press, 1998), 195-229.

Küçük, Cevdet. Ege Adalarının Egemenlik Devri Tarihçesi. Ankara: SAEMK, 2001.

Mert, Özcan, “Tanzimat Dönemi’nde Çeşme Kocabaşıları (1839-1876).” Ankara Universitesi Dil ve Tarih Coğrafya Fakültesi, Tarih Bölümü Tarih Araştırmaları Dergisi, C. 22, S. 35, (2004): 139-154.

Michavelli, Niccolo. The Prince [Prens]. New York: Dover Publications, 1992.

Milas, Herkül. Geçmişten Bugüne Yunanlar. İstanbul: İletişim Yayınları, 2003.

Örenç, Ali. "1821 Yunan İsyanı Sonrası Sisam Adası'na Verilen Yeni Statü.” Tarih Dergisi, S. 36 (2000): 335-346.

Özsüer, Esra "19. Yüzyıl Avrupa Romantiklerinin 1821 Mora İsyanı Üzerindeki Siyasal ve Kültürel Etkileri.” Türkiyat Mecmuası, C. 26, S. 2 (2016): 325-344.

Philliou, Christine M. World, Old and New: Phanariot Networks and the Remaking of Ottoman Governance int the First Half of the Nineteenth Century [Eski ve Yeni Dünya: Fenerli İletişim Ağları ve 19. Yüzyıl'ın Başında Osmanlı Yönetiminin Yeniden Yapılanması] (Doktora Tezi, Princeton Universitesi Tarih Bölümü, Princeton): 2004.

Salzmann, Ariel. "An Ancien Régime Revisited: Privatization and Political Economy in the Eighteenth Century Ottoman Empire.” [Eski Rejimi Yeniden Düşünmek: 18. Yüzy1l Osmanlı İmparatorluğu'nda Özelleştirme ve Politk Ekonomi]. Politics and Society, S. 21 (Aralık 1993): $393-423$

Tansuğ, Feryal, "The Kocabaşıs as Intermediaries?: The Local and Central Administration in Imvros/Imroz and Lemnos in the Early 19th Century." [Aracı Kocabaşı1ar: 19. Yüzyılın Başlarında İmroz ve Limni'de Yerel ve Merkezî Yönetim ] Belleten, C. LXXVIII, S. 281, (Nisan, 2014): 223-244.

Veinstein, Gilles, "Le Patrimoine Foncier De Panayote Benakis, Kocabaşı de Kalamata," Journal of Turkish Studies, C. 11, (1987): 211-233.

Weber, Max. The Vocation Lectures, "Science as a Vocation, "Politics as a Vocation" 
[Meslek Dersleri, "Meslek Olarak Bilim" "Meslek Olarak Politika] Çev: Rodney Livingstone Indianapolis, Cambridge: Hackett Publishing Company, 2004.

Wright, Christopher. The Gattilusio Lordships and The Aegean World, 1355-1462, Leiden: Brill, 2014.

Yaman, Ahmet. “Zimmî”, DIA, C. 44 (İstanbul, 2017), 434-438.

Yaşar, Filiz. Yunan Bağımsızlık Savaşı'nda Sakız Adası, Ankara: Phoenix, 2006. 